\title{
A aÇão popular Como instrumento de tUtela Coletiva no direito BRASILEIRO E NO DIREITO PORTUGUÊS
}

\author{
Action popular as a tool of collective protection in brazilian \\ portuguese law and law
}

JuVÊNCIO Borges SiLva

Docente do programa de Mestrado em Direito da Universidade de Ribeirão Preto - UNAERP. Pós-doutor em Direito pela Universidade de Coimbra, Doutor pela UNESP e mestre pela UNICAMP. E-mail: juvborges@netsite.com.br

José Querino Tavares Neto

Pós-doutor em Direito Constitucional pela Universidade de Coimbra com bolsa Capes, consultor das Faculdades Atenas de Paracatu. Docente adjunto da Faculdade de Direito da Universidade Federal de Goiás. Professor do Programa de Mestrado e Doutorado em Direito da PUC/PR. E-mail: josequerinotavares@gmail.com

RECEBIDO EM: 10.03.2014

APROVADO EM: 20.06.2014

\section{Resumo}

O presente artigo analisa a tutela coletiva em Portugal e Brasil, com foco na Ação Popular, um dos mais antigos instrumentos de tutela coletiva em ambos os países. O objetivo é verificar a relevância, semelhanças e dessemelhanças deste instituto jurídico nos dois países que tem um antigo lastro histórico e cultural. Cuida-se, portanto de um estudo voltado para a tutela coletiva, com campo de estudo delimitado entre o direito brasileiro e português, valendo-se de análise comparativa e de metodologia analítico-dedutiva. A pesquisa revelará a importância destes institutos para os dois países, sendo que se perceberá que a ação popular se reveste de grande importância no direito lusitano, sendo o seu mais importante instrumento de tutela coletiva, bem como se observará que o Brasil experimenta atualmente maiores avanços que Portugal no que se refere à institucionalização dos institutos da tutela coletiva, o que não significa, necessariamente, maior eficácia.

Palavras-chave: Aç̃õo popular. Tutela coletiva. Direito brasileiro. Direito porTUGUÊS. 


\begin{abstract}
This article analyzes the collective protection in Portugal and Brazil, focusing on Class Action, one of the oldest instruments of collective protection in both countries. The goal is to verify the relevance, similarities and dissimilarities of this legal institution in the two countries which has an ancient historical and cultural ballast. Take care, therefore a study on the collective protection, delimited with field study between the Brazilian and Portuguese law, drawing on comparative analysis and analytical-deductive methodology. The research will reveal the importance of these institutions to the two countries, and realize that if the class action is of great importance in the lusitanian law, being its most important instrument of collective protection, as well as notice that Brazil currently experiencing the greatest advances that Portugal with regard to the institutionalization of collective protection of the institutes, which does not necessarily mean greater efficiency.
\end{abstract}

Keywords: Class action. Collective protection. Brazilian law. Portuguese law.

SuMÁRIO: Introdução. 1. A ação popular como instrumento legal e jurídico-processual metaindividual no direito brasileiro e português. 1.1. A ação popular: seu objeto. 1.2. A legitimação para a propositura da ação popular. 1.2.1. Legitimidade individual. 1.2.2. Legitimidade coletiva. 1.2.3. Legitimidade das autarquias locais. 2. A participação do Ministério Público. 3. Sistema especial de representação. 4. O controle da legitimidade popular. 5. Ação popular: coisa julgada e direito de autoexclusão. 5.1. Coisa julgada: noções gerais. 5.2. Coisa julgada formal e material. 5.3. Coisa julgada objetiva e subjetiva. 6 . Avaliação da aplicabilidade da ação popular no direito brasileiro e no direito português. Conclusão. Referências.

\title{
INTRODUÇÃo
}

Os direitos coletivos emergiram como resultado dos conflitos sociais que foram se avolumando ao longo dos séculos XVIII, XIX e XX. O desenvolvimento do capitalismo, as revoluções liberais dos séculos XVII e XVIII, a eclosão da Revolução Industrial no século XVIII, as transformações sociais ocorridas durante o século XIX, acompanhadas da exploração do trabalhador, os avanços científicos e tecnológicos, o surgimento dos movimentos sociais e das ideologias sociais, as duas grandes guerras do século XX, levaram à consciência da necessidade de se instituir 
alguns direitos sociais que pudessem contemplar o bem estar da sociedade como um todo, como saúde, educação, segurança, salário mínimo ao trabalhador, descanso semanal remunerado, férias etc. (OTERO, 1999, p. 267-301).

A instituição dos direitos sociais exigiu uma mudança do paradigma liberal, individual, para o paradigma social. Não se podia mais conceber que em nome dos direitos individuais a coletividade ficasse privada do acesso aos bens e serviços necessários a uma vida digna. Surge assim o Estado de Bem-Estar Social. O Estado, que até então tinha obrigações negativas, agora passa a ter obrigações positivas, passa a realizar ações com vistas a proteger o corpo social. Surge o Estado intervencionista, o Estado que deve atuar na promoção do bem comum (QUEIROZ, 2006, pp. 25-62).

Com o passar do tempo, passa-se à consciência de que alguns direitos envolvem toda uma coletividade, não sendo apenas direitos de alguns indivíduos, mas o direito de um grande número de indivíduos, não podendo mais ser pensados como direitos individuais, mas como direitos coletivos. Surgem de início os direitos coletivos dos trabalhadores até o direito a um meio ambiente saudável. (BOBBIO, 1992, pp. 49-84) Estes direitos, denominados de coletivos, passam a ser inseridos nas constituições e no direito ordinário dos países ocidentais, além de ser objeto de convenções internacionais.

Percebe-se, a seguir, que o sistema processual vigente, não é compatível com o objeto dos direitos coletivos e das ações coletivas, uma vez que os Códigos de Processo foram elaborados sob a ótica do direito liberal, para atender à solução dos conflitos interindividuais, orientados por uma visão privatista do direito (SOUSA, 2003, p. 59-69). É assim que algumas leis específicas são criadas para atender à necessidade de um procedimento processual compatível com as exigências dos processos coletivos: Ação Popular, Ação Civil Pública, dentre outros.

No Brasil, vinha sendo fomentada a ideia, materializada no Anteprojeto do Código de Processo Coletivo (Projeto de Lei 5.139/2009), da edição de um Código de Processo Coletivo, com uma jurisdição coletiva, específica para o tratamento das demandas coletivas (GRINOVER, 2007, pp. 11-15). Apesar de a Comissão de Constituição e Justiça do Congresso Nacional Brasileiro ter rejeitado o projeto ${ }^{1}$, as preocupações concernentes à necessidade de uma tutela coletiva processual não se exauriu.

Em Portugal tem havido, de igual forma, a consciência da necessidade de procedimentos específicos para o tratamento das ações que envolvem interesses da coletividade. Assim, o que aqui se pretende é estabelecer uma análise comparativa entre a Ação Popular no direito brasileiro e português para a tutela dos direitos coletivos.

Entendemos que a proximidade histórica entre Brasil e Portugal justifica

\footnotetext{
${ }_{1}$ Disponível em: http://www.camara.gov.br/sileg/Prop_Detalhe.asp?id=432485, Acessado em: 01.11.2013.
} 
a presente pesquisa, com vistas a aferir o desenvolvimento dos direitos coletivos nestes dois países, considerando suas semelhanças e dessemelhanças, bem como sua relevância no ordenamento jurídico e sua aplicabilidade nos dois países.

\section{A aÇão POPUlar COMO INSTRUMENTO LEGAl E JURídiCO-PROCESSUAL ME- TAINDIVIDUAL NO DIREITO BRASILEIRO E PORTUGUÊS}

A ação popular é certamente o instrumento processual por excelência no direito português para a tutela dos interesses difusos, coletivos e individuais homogêneos, razão pela qual merece consideração mais acurada. É o que se pretende analisar nos próximos tópicos, analisando o objeto da ação, legitimidade, procedimentos, alcance, controle, coisa julgada, etc., estabelecendo a comparação com o mesmo instituto no direito brasileiro.

\subsection{A AÇão POPUlar: SEU OBJETO}

A Lei 4.717/65 (Lei da Ação Popular) estabelece em seu artigo $1^{\circ}$ :

Art. $1^{\circ}$ Qualquer cidadão será parte legítima para pleitear a anulação ou a declaração de nulidade de atos lesivos ao patrimônio da União, do Distrito Federal, dos Estados, dos Municípios, de entidades autárquicas, de sociedades de economia mista (Constituição, art. 141, § 38), de sociedades mútuas de seguro nas quais a União represente os segurados ausentes, de empresas públicas, de serviços sociais autônomos, de instituições ou fundações para cuja criação ou custeio o tesouro público haja concorrido ou concorra com mais de cinqüenta por cento do patrimônio ou da receita ânua, de empresas incorporadas ao patrimônio da União, do Distrito $\mathrm{Fe}$ deral, dos Estados e dos Municípios, e de quaisquer pessoas jurídicas ou entidades subvencionadas pelos cofres públicos.

Fica claro do artigo $1^{\circ}$ da Lei 4.717/65, que a ação popular é o instrumento apto a ser utilizado para se buscar a anulação ou nulidade dos atos lesivos ao patrimônio público. Qualquer cidadão brasileiro, e somente o cidadão, com exclusão de todos os demais, pode ser ator na ação popular, bastando que comprove sua titularidade através do título de eleitor. O Ministério Público é chamado a acompanhar a ação, mas não tem legitimidade para propô-la. Diferentemente ocorre com a "acção popular" portuguesa (Lei $n^{\circ} 83$ de 23 de agosto de 1995) que é uma acção popular constitucional.

A Constituição da República Portuguesa, em seu artigo 52º n. 1 assim dispõe: 


\begin{abstract}
ARTIGO $52^{\circ}$ - (Direito de petição e direito de acção popular)
1. Todos os cidadãos têm o direito de apresentar, individual ou colectivamente, aos órgãos de soberania, aos órgãos de governo próprio das regiões autônomas ou a quaisquer autoridades petições, representações, reclamações ou queixas para defesa dos seus direitos, da Constituição, das leis ou do interesse geral e, bem assim, o direito de serem informados, em prazo razoável, sobre o resultado da respectiva apreciação.

2. A lei fixa as condições em que as petições apresentadas colectivamente à Assembléia da República e às Assembléias Legislativas das regiões autônomas são apreciadas em reunião plenária.

3. É conferido a todos, pessoalmente ou através de associações de defesa dos interesses em causa, o direito de acção popular nos casos e termos previstos na lei, incluindo o direito de requerer para o lesado ou lesados a correspondente indemnização, nomeadamente para:

a) Promover a prevenção, a cessação ou a perseguição judicial das infracções contra a saúde pública, os direitos dos consumidores, a qualidade de vida e a preservação do ambiente e do patrimônio cultural;

b) Assegurar a defesa dos bens do Estado, das regiões autônomas e das autarquias locais.
\end{abstract}

\title{
A Lei 83/95 (LAP) disciplinou em seu artigo $2^{\circ}$, 1, que
}

São titulares do direito procedimental de participação popular e do direito de acção popular quaisquer cidadãos no gozo dos seus direitos civis e políticos e as associações e fundações defensoras dos interesses previstos no artigo anterior, independentemente de terem ou não interesse directo na demanda.

A LAP, em seu $\operatorname{art}^{\circ} 1^{\circ}$, II estipula que são designadamente interesses protegidos pela presente lei "a saúde pública, o ambiente, a qualidade de vida, a proteção do consumo de bens e serviços, o patrimônio cultural e o domínio público". Entretanto, cabe observar que o Ministério Público não tem legitimidade para propor a ação popular em Portugal, tão somente, nos termos do artigo $16^{\circ}$ da LAP "fiscaliza a legalidade e representa o Estado quando este for parte na causa, os ausentes, os menores e demais incapazes, neste último caso quer sejam autores ou réus". O Ministério Público "poderá ainda representar outras pessoas colectivas públicas quando tal for autorizado por lei" (art. 16, 2 ), e poderá ainda, na qualidade de fiscal da legalidade vir a substituir o autor "em caso de desistência da lide, bem como de transacção ou de comportamentos lesivos dos interesses em causa" (art. 16 $6^{\circ}, 3$ ).

A ação popular portuguesa procura garantir a efetiva tutela dos interesses coletivos sob quatro finalidades: a) prevenção; b) cessação; c) perseguição e d) inde- 
nização das infrações contra os bens jurídicos tutelados. É assim que Otero (1999, p. 877 e 878) discorre sobre o objeto da ação popular:

Quanto ao objecto da acção popular, a Constituição, uma vez mais sem excluir a intervenção ampliativa do legislador, estabelece que aquela só pode traduzir numa das cinco modalidades de acção judicial:

(i) Pode tratar-se de uma acção que tem por objecto prevenir infracções contra certos interesses gerais da colectividade, falando-se aqui em acção popular preventiva;

(ii) Poderá ocorrer que a acção popular sirva de instrumento tendente a determinar a cessação de tais infracções, existindo aqui uma acção popular destrutiva ou anulatória;

(iii) Pode a acção popular visar, por outro lado, a perseguição judicial de certo tipo de infracções ou, talvez de modo mais rigoroso, dos agentes protagonistas de tais infracções, deparando-se aqui com uma acção popular repressiva;

(iv) A acção mostra-se ainda susceptível de visar o ressarcimento de danos decorrentes da infracção aos referidos interesses da comunidade, situação em que depararemos com uma acção popular indemnizatória;

(v) Por último, a acção popular poderá visar a defesa de bens integrantes do patrimônio de entidades públicas, especialmente em casos de omissão ou negligência de actuação pública na sua defesa, situação esta reconduzível à tradicional acção popular supletiva ou substitutiva.

O objeto da ação popular é desta forma, bem especificado e amplo. Entretanto, os artigos $22^{\circ}$ e $23^{\circ}$ da Lei da Ação Popular (LAP) impõem o dever de indenizar o(s) lesado(s) pelos danos decorrentes de violação dolosa ou culposa aos interesses acima referidos sem esclarecer, contudo, se na ação popular pode ser deduzido o respectivo pedido.

Aspecto que também chama a atenção na LAP é o que se refere à hipótese em que não seja possível identificar os titulares do direito à indenização (art. 22 $\left.2^{\circ}, 2\right)$, caso em que o valor da indenização deverá ser arbitrado globalmente. Destaca-se aqui duas omissões: a) o legislador não estabeleceu se essa indenização global só pode ser requerida pelo autor ou se é permitido ao juiz fixá-la ex officio; e ainda b) qual o destino da indenização fixada.

F. Nicolau dos Santos Silva (2002, p. 110) assim pondera sobre a possibilidade de pedido indenizatório na ação popular:

Considera-se, pois, que o $\mathrm{n}^{\mathrm{o}} 1$ do artigo $22^{\circ}$ da LAP consagra o princípio geral de que os danos causados pela violação dos interesses individuais homogêneos, colectivos e difusos, que recaíam sobre o ambiente, qualidade 
de vida, patrimônio cultural e consumo de bens e serviços, são indemnizáveis através da acção popular. E que, quando os titulares destes interesses estejam identificados, deve a indemnização ser fixada individualmente e reclamada no prazo de três anos, revertendo, decorrido esse prazo, a favor do Ministério da Justiça, que a efectuará ao pagamento de procuradoria e no apoio ao acesso aos tribunais dos titulares de acção popular.

Se os titulares dos interesses supra-individuais não estiverem identificados, então, de acordo com o que dispõe o $n^{\circ} 2$ do artigo $22^{\circ}$ da LAP, o juiz deve fixar globalmente a indemnização.

Quanto ao destino a dar a esta indemnização, a LAP é omissa, todavia, a mesma deve ser afecta, em primeiro lugar, nos termos gerais, a "reconstituir a situação que existiria, se não se tivesse verificado o evento que obriga à reparação".

Nos casos em que a reconstituição natural não seja possível, ou não repare integralmente os danos ou seja excessivamente onerosa para o agente (se a reconstituição natural pudesse, alguma vez, considerar-se excessivamente onerosa), colocar-se-á, então, o problema de saber qual o destino a dar à indemnização em dinheiro.

Embora se discorde da solução do $\mathrm{n}^{\circ} 5$ do artigo $22^{\circ}$ da LAP, não repugna que a mesma seja aplicada, revertendo para o fundo do Ministério da Justiça destinado a apoio ao acesso aos tribunais neste âmbito.

Cabe ressaltar que o Supremo Tribunal de Justiça de Portugal, em decisão proferida em Acção Popular Civil de tipo declarativo movida pela Associação de Consumidores de Portugal (ACOP) contra "Portugal Telecom S.A.", em sede de Agravo, no dia 23.09.1997, sendo relator o ministro Miranda Gusmão, processo SJ199709230005032 ${ }^{2}$, por unanimidade decidiu, reconhecendo preliminarmente no Acórdão que:

I- O artigo 1 da Lei 83/95, de 31 de Agosto, abrange não só os “interesses difusos" (interesses de toda a comunidade) como ainda os "interesses individuais homogéneos" (os que se polarizam em aglomerados identificados de titulares paralelamente justapostos). II - O direito de reparação de danos dos assinantes do serviço telefónico por incumprimento de contrato incluise na categoria dos “interesses homogéneos individuais". III - A ACOP (Associação de Consumidores de Portugal) tem legitimidade para propor acção popular que tenha por objecto o pedido de indemnização dos assinantes de contrato de serviço telefónico público por violação contratual da prestadora do serviço.

\footnotetext{
${ }^{2}$ http://www.dgsi.pt/jstj.nsf/954f0ce6ad9dd8b980256b5f003fa814/5c4988169839a2ed802568fc003b7c49?OpenDocument. Acessado em: 07.11.2013.
} 
No que tange ao destino da indenização global, face a não-identificação dos lesados, e tendo em vista o que dispõe o artigo 562 do Código Civil: "Quem estiver obrigado a reparar um dano deve reconstituir a situação que existiria, se não se tivesse verificado o evento que obriga à reparação". O valor deve ser destinado à reconstrução da situação em que se encontrava.

O que se observa é que "a legislação portuguesa estabeleceu um único instrumento processual - a ação popular - para a defesa de interesses ligados ao patrimônio público (em sentido lato, compreendendo o patrimônio cultural) e a outros bens comunitários, que especifica”. (GRINOVER, 2000, p. 49). E aponta ainda Grinover (2000, p. 49) os institutos existentes no Brasil.

Diversamente, no ordenamento brasileiro são duas as vias processuais que podem ser utilizadas para esse fim: a defesa do patrimônio público (em sentido lato, compreendendo bens e direitos de valor econômico, artístico, estético, histórico e turístico) e da moralidade administrativa é feita por intermédio da ação popular constitucional (Lei $n^{0} 4.717 / 65$, com as modificações da Lei $\left.n^{\circ} 6.513 / 77\right)$, mais antiga, em que a titularidade da ação é atribuída exclusivamente ao cidadão brasileiro. E a defesa de todo e qualquer interesse ou direito difuso, coletivo ou individual homogêneo se perfaz pela denominada "ação civil pública", com titularidade ao Ministério Público e a corpos intermediários (Lei $n^{\circ} 7.347 / 85$, ampliada pelo Código de Defesa do Consumidor - Lei $\left.n^{\circ} 8.078 / 90\right)$.

Questão posta por Grinover (2000) é se o rol de interesses indicados no art. $1^{\circ}$ da LAP deve ser interpretado como sendo taxativo ou meramente exemplificativo, obtemperando que se espera sejam meramente exemplificativos, tendo em vista a gama de direitos que vão surgindo e que exigem a tutela coletiva pelo Estado. Nesse aspecto, o legislador brasileiro, em sede de cautela, não se satisfez com um rol de interesses metaindividuais taxativo, pois, após elencar vários direitos metaindividuais acrescentou a expressão: "qualquer outro interesse difuso ou coletivo" (art. 1 ${ }^{\circ}, \mathrm{IV}$, da Lei $\left.n^{0} 7.347 / 85\right)$.

Otero (1999, pp. 871-872) muito bem explicitou os fins da acção popular em Portugal:

1.1. A acção popular, sendo sempre uma acção judicial e, neste sentido, a expressão do direito fundamental de acesso aos tribunais, distingue-se de todas as demais modalidades de acções pela amplitude dos critérios determinativos da legitimidade para a respectiva propositura.

1.2. Mediante a acção popular, pode dizer-se que todos os membros de uma comunidade - ou, pelo menos, um grupo de pessoas não individualizável pela titularidade de qualquer interesse directamente pessoal - estão 
investidos de um poder de acesso à justiça visando tutelar situações jurídicas materiais que são insuceptíveis de uma apropriação individual.

A acção popular traduz, deste modo, uma forma de tutela jurisdicional de posições jurídicas materiais que, sendo pertença de todos os membros de uma certa comunidade, não são, todavia, apropriáveis por nenhum deles em termos individuais. Deparamos aqui, por isso mesmo, com um conjunto de interesses materiais solidariamente comuns aos membros de uma comunidade e cuja titularidade se mostra indivisível através de um processo de apropriação individual.

Neste sentido, deverá afirmar-se que o actor popular age sempre no interesse geral da colectividade ou da comunidade a que pertence ou se encontra inserido, isto sem que tal meio de tutela judicial envolva a titularidade de qualquer interesse directo e pessoal.

A ação popular portuguesa, portanto, visa tutelar direitos coletivos, de interesse geral da coletividade, sendo competente para a persecução dos direitos coletivos, difusos e inclusive dos individuais homogêneos, conforme acórdão supracitado do Supremo Tribunal de Justiça. Diferentemente, no direito brasileiro, além da proteção aos bens públicos pela Ação Popular, a persecução de todos os demais direitos difusos, coletivos e individuais homogêneos se dá através da ação civil pública.

\subsection{A legitimaÇão Para a PROPOSitura da AÇão POPUlar}

Otero $(1999$, p. 877) reconhece dois modelos de ação popular:

a) Em termos de legitimidade activa, a Constituição consagra dois modelos de acção popular:

(i) Temos, por um lado, a acção popular desencadeada em termos pessoais, representando aquilo que se pode chamar a acção popular individual;

(ii) Reconhece-se, por outro lado, a possibilidade de associações de defesa de certos interesses poderem também desencadear a acção popular, caso este que se reconduz a uma acção popular colectiva.

Reconhece, portanto, Otero, a acção popular individual e a acção popular colectiva.

Quanto à titularidade para a propositura da ação popular assim se posiciona Otero (1999, p. 882):

a) Em primeiro lugar, a titularidade do direito de acção popular ou, segundo outra perspectiva, a legitimidade activa da acção popular encontra-se distribuída nos seguintes termos: 
(i) Quanto à acção popular individual, têm legitimidade para a desencadear quaisquer cidadãos no gozo dos seus direitos civis e políticos;

(ii) No que respeita à acção popular colectiva, a lei conferiu legitimidade às associações e fundações defensoras dos interesses a que se refere o artigo $32^{\circ}, n^{\circ} 3$, da Constituição, isto desde que se verifiquem certos requisitos em tais entidades;

(iii) No âmbito da liberdade conformadora do legislador conferida pela Constituição, a Lei $n^{0}$ 83/95 criou ainda, por outro lado, uma forma de acção popular pública, conferindo às autarquias locais legitimidade activa processual relativamente "aos interesses de que sejam titulares residentes na área da respectiva circunscrição.

Ademais, há que se pontuar que o legislador português, procurando harmonizar a LAP com o Código de Processo Civil, fez constar deste, dispositivo que visa estabelecer a harmonia com os princípios orientativos da Ação Popular. É assim que dispõe o art. 26 do CPC:

Tem legitimidade para propor e intervir nas ações e procedimentos cautelares destinados, designadamente, à defesa da saúde pública, do ambiente, da qualidade de vida, do patrimônio cultural e do domínio público, bem como à proteção do consumo de bens e serviços, qualquer cidadão no gozo de seus direitos civis e políticos, as associações e fundações defensoras dos interesses em causa, as autarquias locais e o Ministério Público, nos termos previstos na lei.

A seguir, vejamos as implicações decorrentes do critério legal conforme a classificação de Otero no que se refere à legitimação.

\subsubsection{Legitimidade individual}

A Lei 83/95 (Acção Popular) assim dispõe em seus artigos $2^{\circ}$ e $3^{\circ}$ :

\section{Art. $2^{\circ}$ - (Titularidade dos direitos de participação procedimental e do direito de acção popular)}

1. São titulares do direito procedimental de participação popular e do direito de acção popular quaisquer cidadãos no gozo dos seus direitos civis e políticos e as associações e fundações defensoras dos interesses previstos no artigo anterior, independentemente de terem ou não interesse directo na demanda.

2. São igualmente titulares dos direitos referidos no número anterior as autarquias locais em relação aos interesses de que sejam titulares residentes

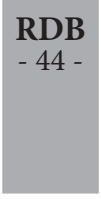


na área da respectiva circunscrição.

\section{Art. $3^{\circ}$ - (Legitimidade activa das associações e fundações)}

Constituem requisitos da legitimidade activa das associações e fundações:

a) personalidade jurídica;

b) O incluírem expressamente nas suas atribuições ou nos seus objetivos estatutários a defesa dos interesses em causa no tipo de acção de que se trate;

c) Não exercerem qualquer tipo de actividade profissional concorrente com empresas ou profissionais liberais.

Quanto ao mandato representativo, assim dispõe a Lei 83/95 em seu artigo 14:

\section{ARTIGO $14^{\circ}$ - (Regime especial de representação processual)}

Nos processos de acção popular, o autor representa por iniciativa própria, com dispensa de mandato ou autorização expressa, todos os demais titulares dos direitos ou interesses em causa que não tenham exercido o direito de auto-exclusão previsto no artigo seguinte, com as conseqüências constantes da presente lei.

Como observa Grinover (2000, p. 52), "a legitimação da lei portuguesa parece ser concorrente e autônoma, no sentido de que a legitimidade de um não exclui a de outro, podendo qualquer dos legitimados exercer o direito de ação, sem necessidade de intervenção dos demais. Assim também ocorre no Brasil para a ação civil pública”.

A legitimação para a propositura da ação popular portuguesa é exclusivamente determinada por lei, não podendo o juiz indeferir a inicial quanto à legitimação, na medida em que esta estiver contemplada em lei, mas somente quando entender "ser manifestamente improvável a procedência do pedido, ouvido o Ministério Público e feitas, preliminarmente, as averiguações que o julgador tenha por justificadas ou que o autor ou o Ministério Público requeiram (art. 13)". (GRINOVER, 2000, p. 52). Trata-se aqui do indeferimento da inicial por ausência do fumus boni iuris, e não da aferição da representatividade como elemento essencial da legitimação para agir.

Ferraresi (2007, p. 136) observa que "nos moldes atuais, as ações coletivas brasileiras iniciam-se pelos legitimados indicados expressamente na Lei da Ação Civil Pública (Lei 7.347/85) e no Código de Defesa do Consumidor (Lei 8.070/90), permitindo-se ao cidadão ajuizar a ação popular constitucional (Lei 4.717/65)." E considerando que os elencados para a propositura das ações coletivas segundo a Lei da Ação Civil Pública e Código de Defesa do Consumidor são tão somente o Ministério Público, a União, os Estados, os Municípios, o Distrito Federal, as entidades e órgãos da Administração Pública direta ou indireta, ainda que sem personalidade 
jurídica e especificamente destinados à defesa dos interesses e direitos supraindividuais, e as associações legalmente constituídas há pelo menos um ano e que tenham pertinência temática com os interesses defendidos, restou ao indivíduo a ação popular como único instrumento processual de ação coletiva.

Ferraresi aponta algumas razões pelas quais o legislador brasileiro não contemplou o indivíduo como titular em todas as ações coletivas:

Qual a razão de se retirar do indivíduo a possibilidade de ajuizar uma ação coletiva?

O caráter político e a experiência oriunda da ação popular, utilizada com freqüência "como instrumento político de pressão e até de vindita, serviram para o perfilhamento da opção legislativa mencionada". Como já existe a ação popular, não haveria necessidade de se outorgar outro instrumento ao cidadão para a defesa dos interesses supra-individuais em juízo. Temia-se com isso a banalização das demandas coletivas.

Diz-se, também, que o cidadão brasileiro ainda não está preparado para utilizar judicialmente as ações coletivas e que, se essa possibilidade the fosse aberta, teríamos um enorme número de demandas sem relevância, o que retiraria a força e a credibilidade desse instrumento.

Poder-se-ia ainda pensar que o sistema da legitimidade individual às ações coletivas é tipicamente norte-americano, fugindo completamente de nossas tradições e de nossas raízes jurídicas. A nossa sociedade não é esclarecida e, por isso, haveria a necessidade de que órgãos estatais ou mesmo corpos intermediários respondessem pelas demandas coletivas.(FERRARESI, 2007, pp. 136-137).

Ferraresi (2007, p. 137) rechaça totalmente tais argumentos, afirmando que "legitimar a pessoa física estimularia a propositura de ações coletivas, tornando o cidadão mais responsável pela defesa dos interesses supra-individuais”, suprindo, neste caso, a ausência do Ministério Público, de vez que este não tem condições de estar em todo o lugar.

Nesse ponto, o direito português avançou para além do direito brasileiro, ao conferir ao cidadão legitimidade para a propositura da ação popular, que é o instrumento hábil para qualquer ação coletiva.

A legislação portuguesa afirma que o autor da ação popular representa, por iniciativa própria, com dispensa de mandato ou autorização expressa, todos os titulares dos direitos ou interesses em causa que não tenham exercido o direito de auto-exclusão.

Não figurou o Ministério Público como titular da ação popular portuguesa, cabendo-lhe exercer a função de fiscal. Entretanto, poderá, querendo, subs- 
tituir-se ao autor quando este desistir da demanda, transacionar ou tenha comportamentos lesivos dos interesses em causa, solução equivalente à adotada pela ação popular brasileira. (FERRARESI, 2007, p. 141).

Caminhou bem o direito português ao conferir a legitimidade a "quaisquer cidadãos no gozo dos seus direitos civis e políticos" (legitimidade individual) para a propositura da ação popular, "independentemente de terem ou não interesse directo na demanda". Ou seja, o direito de ação popular difere do tradicional direito de ação, de vez que este pressupõe a titularidade de um interesse direto na situação jurídica, enquanto aquele a dispensa.

Sousa (2003, p. 178) critica a restrição da legitimidade para a propositura da ação popular aos cidadãos portugueses:

A exigência de que o cidadão esteja no gozo dos seus direitos políticos que é realizada pelo $\operatorname{art}^{\circ} 2^{\circ}, \mathrm{n}^{\mathrm{o}} 1$, LPPAP levanta um problema: como o $\operatorname{art}^{\circ} 15^{\circ}$, $\mathrm{n}^{\circ} 2$, CRP reserva aos cidadãos portugueses os direitos políticos, coloca-se a questão de saber se um cidadão estrangeiro pode ser titular do direito de acção popular. Dado que o $\operatorname{art}^{\circ} 52^{\circ}, \mathrm{n}^{\circ} 3, \mathrm{CRP}$ trata em conjunto o direito de petição e o direito de acção popular, sendo ambos direitos de participação política, tem interesse verificar qual o regime que se encontra estabelecido para aquele direito de petição. O panorama é o seguinte: - o direito de petição é exclusivo dos cidadãos portugueses ( $\left.\operatorname{art}^{\circ} 4^{\circ}, n^{\circ} 2, \mathrm{~L} 43 / 90\right)$. Portanto, aplicando ao direito de acção popular o regime estabelecido para o lugar paralelo do direito de petição, pode concluir-se que qualquer estrangeiro e apátrida residente em território português pode propor uma ação popular se a finalidade desta for a tutela de interesses relativos a essa qualidade.

Em todo caso, não parece que se deva recusar a legitimidade popular a estrangeiros e apátridas residentes em Portugal, mesmo que a acção popular não tenha por finalidade a tutela de interesses ligados a essa sua qualidade. $\mathrm{O}$ direito de acção popular não deve ser considerado um direito político reservado pelo art. $15^{\circ}, \mathrm{n}^{\circ} 2, \mathrm{CRP}$ aos cidadãos portugueses, porque ninguém pode estar impedido de recorrer aos tribunais para defesa dos seus interesses. Assim, de acordo com o princípio da equiparação estabelecido no $\operatorname{art}^{\circ} 15^{\circ}, n^{\circ} 1, C R P$, há que reconhecer legitimidade popular a cidadãos estrangeiros e a apátridas, desde que os mesmos se encontrem ou residam em Portugal.

Desta forma, Sousa preconiza que o direito de ação popular com titularidade individual deve ser o mais amplo possível, sem estabelecer restrição a quem quer que seja. 


\subsubsection{Legitimidade coletiva}

No que tange à legitimidade para a propositura da ação popular por pessoas coletivas, percebe-se que o legislador português não demonstrou a mesma liberalidade como o fez com a titularidade individual, pois a Lei de Ação Popular (Lei 83/95, art. $3^{\circ}$ ) fixou os seguintes requisitos quanto à legitimidade:

$1^{\circ}$ - possuir personalidade jurídica $\left(\operatorname{art.~} 3^{\circ}, a\right)$;

$2^{\mathrm{o}}$ - incluir expressamente em suas atribuições ou objetivos estatutários a defesa dos interesses em causa (art. $\left.3^{\circ}, b\right)$;

$3^{\circ}$ - não exercer qualquer tipo de atividade profissional concorrente com empresas ou profissionais liberais (art. $\left.3^{\circ}, c\right)$.

A Lei da Ação Civil Pública (Lei 7.347/85) também disciplinou em seu artigo $5^{\circ}$ que as entidades civis devem estar juridicamente organizadas há pelo menos um ano e ter incluído entre suas finalidades institucionais, a proteção ao meio ambiente, ao consumidor, à ordem econômica, à livre concorrência ou ao patrimônio artístico, estético, histórico, turístico e paisagístico

Sousa (2003, p. 181) considera que esta parcimônia nos requisitos a concessão de legitimidade popular às pessoas coletivas explica-se pelo carácter concorrente desta legitimidade, e como decorre do estabelecido no $\operatorname{art}^{\circ} 15^{\circ}, \mathrm{n}^{\circ} 1$, LPPAP, devem ser citados para a ação popular todos os titulares do interesse difuso nela defendido, pelo que há sempre a possibilidade de a atuação da organização naquela ação ser controlada pelos interessados.

Observa, também, Sousa (2003, p. 179) que o leque de legitimados foi ampliado pelo legislador ordinário:

Concretizando o disposto no $\operatorname{art}^{\circ} 52^{\circ}, n^{\circ} 3$, CRP, alguma legislação ordinária concede legitimidade popular a associações de defesa de interesses difusos. Importa considerar especialmente as seguintes previsões legais: - os $\left.\operatorname{art}^{\circ} \mathrm{s} 13^{\circ}, \mathrm{AL} . \mathrm{b}\right)$, e $18^{\circ}, \mathrm{n}^{\circ} 1$, al. 1), LDC reconhecem às associações de defesa dos consumidores legitimidade para a propositura de uma acção popular para prevenir, corrigir ou fazer cessar práticas lesivas dos direitos do consumidor ou para exigir a reparação de danos sofridos; - o $\operatorname{art}^{\circ} 26^{\circ}$, $\mathrm{n}^{\mathrm{o}} 1$, al $\mathrm{l}_{\mathrm{a}}^{\mathrm{s}} \mathrm{a}$ ) e b), LCCG atribui às associações de consumidores e às associações sindicais, profissionais ou de interesses económicos legitimidade para a acção inibitória do uso ou recomendação de cláusulas contratuais gerais; o $\operatorname{art}^{\mathrm{o}} 10^{\circ}, \mathrm{al}^{\mathrm{a}} \mathrm{s}$ a) e b), LONGA reconhece às associações de defesa do ambiente (ou às organizações não governamentais de ambiente) legitimidade para a propositura de uma acção popular que pode visar quer a prevenção, a correcção, a suspensão e a cessação de actos ou omissões que possam constituir ou constituam factor de degradação do ambiente, quer a efectivação da responsabilidade civil relativa a esses mesmos actos e

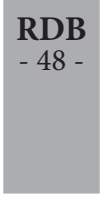


omissões; os $\operatorname{art}^{\circ} \mathrm{s} 31^{\circ}, \mathrm{n}^{\circ} 1$, al. B), e $32^{\circ} \mathrm{CVM}$ conferem às associações de defesa dos investidores legitimidade para a propositura de acções populares para a protecção dos interesses dos investidores não institucionais em valores mobiliários; finalmente, o $\operatorname{art}^{\circ} 10^{\circ}, \mathrm{n}^{\circ} 4$, L 107/201, de 8/9, atribui o direito de acção popular às estruturas associativas de defesa do património cultural.

A tendência, nesta perspectiva, é que cada vez mais seja ampliada a legitimidade para a propositura de ações coletivas em Portugal, viabilizando, desta forma, amplo exercício democrático.

\subsubsection{Legitimidade das autarquias locais}

A legitimidade pertence também às autarquias locais "quando estas procurem defender os interesses dos titulares que tenham residência na área da respectiva circunscrição ( $\operatorname{art}^{\circ} 2^{\circ}, \mathrm{n}^{\mathrm{o}} 2$, LPPAP)". (SOUSA, 2003, p. 200).

É necessário, ainda, além dessa limitação territorial, que a defesa da ação popular se inclua nas suas competências legais, nos termos do art. $2^{\circ}$ da LPPAP. Assim, exemplifica Sousa (2003, p. 200), que

(...) um município pode propor uma acção popular para defesa do patrimônio natural, cultural, paisagístico e urbanístico municipal ( $\mathrm{cfr}^{-} \mathrm{Art}^{\circ} \mathrm{64}^{\circ}$, no 2, al. $m$ ), L 169/99, de 18/9), mas não é concebível que um município ou uma freguesia pretenda combater, através da propositura de uma acção popular, algumas práticas de concorrência desleal que se verifiquem na respectiva circunscrição, pois que isso não cabe nas suas atribuições legais.

\section{A participaÇão do Ministério Público}

Discorrendo sobre a participação do Ministério Público no direito processual coletivo como legitimado ativo, observa Almeida:

Na defesa dos interesses primaciais da sociedade, o Ministério Público deixou de ser o simples guardião da lei (custos legis). Assume agora, pelas razões já expostas, o papel de guardião da sociedade (custos societatis) e, fundamentalmente, de guardião do próprio direito (custos juris), conforme ensinamento de Cláudio Souto.

É sob esta concepção de custos juris que o Ministério Público destacase hoje como o principal legitimado ativo no direito processual coletivo comum. Essa hegemonia do Parquet, como legitimado ativo para a defesa dos interesses massificados, decorre certamente de dois fatores básicos. $\mathrm{O}$ 
primeiro está fundamentado no próprio perfil constitucional, ou seja, Instituição permanente, essencial à função jurisdicional do Estado e defensora da ordem jurídica do regime democrático e dos interesses sociais (art. 127, caput, da $\mathrm{CF}$ ). $\mathrm{O}$ outro fator decorre do próprio exercício prático de suas atribuições constitucionais, visto que é hoje público e notório que o Parquet é a Instituição mais atuante, seja no campo extrajurisdicional, seja no jurisdicional, na tutela dos direitos ou interesses coletivos, especialmente por intermédio do inquérito civil e do ajuizamento de ações civis públicas. Antônio Augusto de Camargo Ferraz faz essa observação ressaltando que, com certeza, mais de $90 \%$ (noventa por cento) dos casos de atuação na defesa dos interesses massificados decorrem da iniciativa do Ministério Público. Expressa ainda esse autor a sua preocupação com essa tímida atuação dos demais legitimados ativos, já que tal situação é efeito da fragilidade de nossa democracia. (ALMEIDA, 2003, pp. 512-513).

O Ministério Público Brasileiro tem amplos poderes para a proteção de todos os direitos difusos, coletivos e individuais homogêneos, sem restrição. Assim, observa Almeida que

restringir a legitimidade ativa do Ministério Público para a defesa dos direitos ou interesses coletivos, em sua tríplice concepção legal (art. 81, parágrafo único, do $\mathrm{CDC}$ ), além de inconstitucional, é postura socialmente perversa: significaria negar acesso à Justiça em face dos interesses primaciais da sociedade, por conseguinte impedindo a efetivação do Estado Democrático de Direito, consagrado no art. $1^{\circ}$ da nossa Constituição Federal". (ALMEIDA, 2003, p. 516).

A atuação do Ministério Público na defesa dos interesses coletivos, nos termos da Ação Popular Portuguesa, por sua vez, é menos abrangente que a atuação do Ministério Público no Brasil, ainda que seja mais atuante se comparado com outros países europeus. Otero (1999, p. 884) aponta duas funções do Ministério Público na Ação Popular:

(...) a acção popular permite que o Ministério Público possa, simultaneamente, desempenhar dois papéis processuais:

(i) Por um lado, o Ministério Público tem a seu cargo a fiscalização da legalidade, incluindo todo o tipo de comportamentos lesivos dos interesses em causa no processo e a própria possibilidade de exercer uma posição substitutiva do acto popular que desencadeou o processo;

(ii) Por outro lado, o Ministério Público tem ainda uma ampla função de representação processual, aqui se integrando a representação do Estado, 
se este for parte na causa, os ausentes, os menores e os demais incapazes, além de poder também ser chamado a representar outras entidades públicas.

Todas estas funções estão dispostas nos artigos $16^{\circ}, \mathrm{n}^{\circ} \mathrm{s} 1$ a $3 ; 18^{\circ}$ e $20^{\circ} \mathrm{n}^{\mathrm{o}} \mathrm{s}$ 1 a 3 da Lei 83/95.

Assim, o Ministério Público de Portugal tem legitimidade para fiscalizar a legalidade das ações, podendo intervir nas ações, mas sem poder para ajuizá-las.

O Estatuto do Ministério Público de Portugal $^{3}$, assim dispõe:

Estrutura e funções

Artigo 1. ${ }^{\circ}$ - Definição

O Ministério Público representa o Estado, defende os interesses que a lei determinar, participa na execução da política criminal definida pelos órgãos de soberania, exerce a acção penal orientada pelo princípio da legalidade e defende a legalidade democrática, nos termos da Constituição, do presente Estatuto e da lei.

\section{Artigo 2. ${ }^{\circ}$ Estatuto}

1 - O Ministério Público goza de autonomia em relação aos demais órgãos do poder central, regional e local, nos termos da presente lei.

2 - A autonomia do Ministério Público caracteriza-se pela sua vinculação a critérios de legalidade e objectividade e pela exclusiva sujeição dos magistrados do Ministério Público às directivas, ordens e instruções previstas nesta lei.

\section{Artigo $3 .^{\circ}$ Competência}

1 - Compete, especialmente, ao Ministério Público:

a) Representar os Estados, as regiões autónomas, as autarquias locais, os incapazes, os incertos e os ausentes em parte incerta;

b) Participar na execução da política criminal definida pelos órgãos de soberania;

c) Exercer a acção penal orientada pelo princípio da legalidade;

d) Exercer o patrocínio oficioso dos trabalhadores e suas famílias na defesa dos seus direitos de carácter social;

e) Assumir, nos casos previstos na lei, a defesa de interesses colectivos e difusos;

f) Defender a independência dos tribunais, na área das suas atribuições,

\footnotetext{
${ }^{3}$ Disponível em: http://www.pgr.pt/ Acessado em: 15.12.2013.
} 
e velar para que a função jurisdicional se exerça em conformidade com a Constituição e as leis;

g) Promover a execução das decisões dos tribunais para que tenha legitimidade;

h) Dirigir a investigação criminal, ainda quando realizada por outras entidades;

i) Promover e realizar acções de prevenção criminal;

j) Fiscalizar a constitucionalidade dos actos normativos;

1) Intervir nos processos de falência e de insolvência e em todos os que envolvam interesse público;

m) Exercer funções consultivas, nos termos desta lei;

n) Fiscalizar a actividade processual dos órgãos de polícia criminal;

o) Recorrer sempre que a decisão seja efeito de conluio das partes no sentido de fraudar a lei ou tenha proferida com violação de lei expressa;

p) Exercer as demais funções conferidas por lei.

Verifica-se que a atuação do Ministério Público português é bastante ampla, sendo que na alínea "e" destaca-se a defesa dos interesses difusos e coletivos nos casos previstos em lei.

A Lei n. 24/96, de 31 de julho (Lei do Consumidor), portanto, posterior à Lei 83/95, estabelece em seu art. $13^{\circ}$ a legitimação do Ministério Público para propor ações relacionadas à relação de consumo. Assim, observa-se que o legislador português tem demonstrado uma tendência crescente na legitimação do Ministério Público para a defesa dos interesses de natureza supra-individual.

Na Ação Popular, todavia, a participação do Ministério Público em Portugal, é mais limitada, conforme disposição do artigo 16 da Lei 83/95:

\section{ARTIGO $16^{\circ}$ - (Ministério Público)}

1. O Ministério Público fiscaliza a legalidade e representa o Estado quando este for parte na causa, os ausentes, os menores e demais incapazes, neste último caso quer sejam autores ou réus.

2. O Ministério Público poderá ainda representar outras pessoas colectivas públicas quando tal for autorizado por lei.

3. No âmbito da fiscalização da legalidade, o Ministério Público poderá, querendo, substituir-se ao autor em caso de desistência da lide, bem como de transacção ou de comportamentos lesivos dos interesses em causa.

O Ministério Público, nos termos legais, não pode propor a demanda, mas pode substituir pessoas coletivas públicas quando a lei autorizar, bem como pode vir a substituir ao autor em caso de desistência da lide. Neste caso, nada obsta a que o Ministério Público tenha atuação nas ações coletivas envolvendo interesses supra -individuais. 
No Brasil, a legitimidade processual na defesa de interesses difusos, coletivos e individuais homogêneos pelo Ministério Público tem sido muito produtiva. Entretanto, a peculiaridade cultural de cada povo deve ser levada em conta no processo legiferante e judicial.

\section{Sistema ESPECIAL DE REPRESENTAÇão}

O legislador português (art. $14^{\circ}$ da Lei 83/95) criou um regime especial de representação para a ação popular:

\section{ARTIGO $14^{\circ}$ - (Regime especial de representação processual)}

Nos processos de acção popular, o autor representa por iniciativa própria, com dispensa de mandato ou autorização expressa, todos os demais titulares dos direitos ou interesses em causa que não tenham exercido o direito de auto-exclusão previsto no artigo seguinte, com as conseqüências constantes da presente lei.

$\mathrm{O}$ artigo em comento dispõe que o autor representa interesses necessariamente supra-individuais, não sendo fundamental que haja uma identificação do autor com o interesse perseguido. Além disso, o artigo 14 dispõe que é dispensado ao autor "mandato ou autorização expressa" dos interessados que são por ele representados. Entretanto, conforme disposto no artigo $15^{\circ}$ da Lei 83/95, os titulares dos interesses em causa na ação serão citados para, no prazo fixado pelo juiz, passarem a intervir no processo a título principal, quando então deverão declarar nos autos "se aceitam ou não ser representados pelo autor ou se, pelo contrário, se excluem dessa representação, nomeadamente para o efeito de lhes não serem aplicáveis as decisões proferidas, sob pena de a sua passividade valer como aceitação, sem prejuízo do disposto no $\mathrm{n}^{\mathrm{o}}$ 4." (art. $\left.15^{\circ}, 1\right)$.

\section{O CONTROLE DA LEGITIMIDADE POPULAR}

Como observa Sousa (2003, p. 203-204), “a legitimação popular deve ser aferida em função de dois elementos: - o poder de representação do autor popular, ou seja, a faculdade que cabe ao demandante de representar os titulares do interesse difuso; - o interesse em demandar do autor popular, isto é, a vantagem que o demandante retira da procedência da acção."

Quanto ao conteúdo do poder por parte do representante na ação popular afirma Sousa (2003, pp. 204-205):

O autor popular somente assume a representação dos titulares do interesse

difuso, mas não é o seu titular, na hipótese de a acção popular ser proposta 
por uma associação, fundação ou autarquia local (cfr. $\operatorname{art}^{0} 2^{\circ}, n^{\circ} \mathrm{s} 1$ e 2, LPPAP), ou não é o seu único titular, no caso de essa acção ser instaurada por um dos titulares do interesse difuso (cfr. $\operatorname{Art}^{\circ} 2^{\circ}, n^{\circ} 1$, LPPAP). Desta circunstância decorre que o autor popular não tem poderes de disposição sobre o interesse difuso e, portanto, não pode praticar na acção popular quaisquer actos que importem a extinção ou a modificação desse interesse. Esta afirmação parece ser contrariada pelo estabelecido no $\operatorname{art}^{\circ} 16, \mathrm{n}^{\mathrm{0}} 3$, LPPAP, dado que este preceito admite que o autor popular possa, embora sujeito a um eventual controlo pelo Ministério Público, desistir da lide ou celebrar uma transacção com o demandado. Todavia, a interpretação do $\operatorname{art}^{\circ} 16^{\circ}, n^{\circ} 3$, LPPAP não impõe esta conclusão.

Antes do mais, não é certamente acidental que o $\operatorname{art}^{\circ} 16^{\circ}, n^{\circ} 3$, LPPAP se refira à desistência da lide e não à desistência do pedido: aquela expressão (aliás, sem tradição no ordenamento jurídico português) parece inculcar que se pretende aludir a uma desistência da acção ou, em termos mais técnicos, a uma desistência da instância, cujo efeito é apenas o de fazer cessar a acção popular pendente ( $c$ fr. $\left.\operatorname{Art}^{\circ} 295^{\circ}, \mathrm{n}^{\circ} 2, \mathrm{CPC}\right)$, sem implicar qualquer disposição do interesse difuso.

Assim, faz-se necessário que um controle da legitimidade popular seja realizado, de forma que o representante atue nos limites dos interesses dos representados. É preciso "assegurar que não existe qualquer conflito de interesses entre aquele demandante e os titulares do interesse difuso, nem entre aquele demandante e o seu mandatário judicial". (SOUSA, 2003, p. 231). Daí, a necessidade de um controle da legitimidade popular.

A representação assumida pelo autor popular deve ser analisada considerando dois factores: esta representação permite que todos os titulares do interesse difuso beneficiem do resultado da acção popular, mas, ao mesmo tempo, a ausência daqueles titulares desta acção pode favorecer que o autor assuma condutas prejudiciais aos interesses daqueles titulares e a falta de controle do demandante sobre o seu advogado também pode conduzir a que este mandatário não defenda adequadamente os interesses daqueles titulares. Na primeira situação, há um conflito (endógeno) entre os titulares do interesse difuso; no segundo, há um conflito (exógeno) entre o mandatário do autor popular e os titulares do interesse difuso. (SOUSA, 2003, pp. 231-232).

Este controle é também realizado pelo Ministério Público. A LPPAP, em seu artigo $16^{\circ}$, 1, "atribuiu ao Ministério Público a fiscalização da legalidade, na ação popular, bem como a representação do Estado, quando for autor, e dos ausentes, menores e demais incapazes, no pólo ativo ou passivo da demanda. (GRINOVER, 2000, p. 56). Aponta ainda Grinover, (203, p. 56) que se permite ainda seja atribuída 
ao Ministério Público, por lei, "a representação de outras pessoas coletivas públicas (art. 16.2); e, finalmente, outorga-lhe poder de impulso, substituindo-se ao autor popular, em caso de desistência do processo, de transação ou de comportamentos lesivos dos interesses em causa (art. 16.3).” Assim, o Ministério Público atua precipuamente como fiscal da lei, e sucessivamente como representante das pessoas coletivas, nos termos da lei.

\section{AÇão POPUlar: Coisa JUlgada e direito de AUtOeXClusão}

\subsection{Coisa JUlgada: NOÇÕES GERAIS}

A sentença judicial, enquanto estiver sujeita a recurso, não se encontra apta a produzir seus regulares efeitos, pois ela pode vir a sofrer alterações, tendo em vista o instituto do duplo grau de jurisdição. Entretanto, há um momento em que a sentença encontra estabilidade e se torna inatacável, seja porque os recursos foram esgotados, ou porque não foram utilizados nos prazos legais.

Uma vez não mais sujeita a recurso, a sentença transita em julgado, tornando-se inatacável. A coisa julgada, portanto, indica o término do processo e a imutabilidade daquilo que nele foi decidido. É o que está disposto no artigo 467 do CPC: "Denomina-se coisa julgada material a eficácia que torna imutável e indiscutível a sentença, não mais sujeita a recurso ordinário ou extraordinário". Com a publicação, a sentença se torna irretratável para o julgador que a proferiu (art. 463). "Mas o vencido pode impugná-la, valendo-se do duplo grau de jurisdição consagrado pelo nosso sistema judiciário e pedindo a outro órgão superior da Justiça que reexamine o julgado. Isso se faz através do recurso". (THEODORO JÚNIOR, 2007, p. 592).

Uma vez que transcorre o prazo legal recursal, sem que o vencido se manifeste, ou depois de decididos todos os recursos interpostos, sem que haja possibilidade de novas impugnações, a sentença torna-se definitiva e imutável.

A coisa julgada tem como fito a segurança na sociedade, impedindo que os conflitos se prolonguem por tempo indefinido, ou então, que venham a ser repetidos consoante vontade dos interessados. A coisa julgada viabiliza, destarte, a segurança jurídica.

O legislador constituinte no Título II, que versa sobre os "direitos e garantias fundamentais", fez constar a coisa julgada em seu artigo $5^{\circ}$, XXXVI, estabelecendo: "A lei não prejudicará o direito adquirido, o ato jurídico perfeito e a coisa julgada". 


\subsection{Coisa JUlgada FORMAL E MATERial}

A coisa julgada se desdobra em coisa julgada formal e coisa julgada material.

O Código de Processo Civil em seu artigo 467 define a coisa julgada material, mas faz-se necessário considerar também a coisa julgada formal.

A coisa julgada formal liga-se ao término do processo. Consiste na imutabilidade da sentença pela preclusão dos prazos para recurso, tornando a sentença imutável no processo no qual foi proferida, cumprindo o Estado a prestação jurisdicional.

Pode vir a ocorrer coisa julgada formal sem que, necessariamente, ocorra a coisa julgada material. Tal ocorre quando as sentenças são terminativas. Neste caso o processo é extinto sem o conhecimento do mérito, possibilitando que a questão seja novamente discutida em outro processo.

A coisa julgada formal atua dentro do processo em que a sentença foi proferida, sem impedir que o objeto do julgamento volte a ser discutido em outro processo. Já a coisa julgada material, revelando a lei das partes, produz seus efeitos no mesmo processo ou em qualquer outro, vedando o reexame da res iudicim deducta, por já definitivamente apreciada e julgada. (THEODORO JÚNIOR, 2007, p. 595).

A coisa julgada material só se realiza nas sentenças de mérito. Via de regra, em ocorrendo a coisa julgada formal, ocorre de igual forma a coisa julgada material, exceto nas sentenças terminativas. Em ocorrendo a coisa julgada material, a matéria objeto do processo em que ocorreu a sentença, não poderá mais ser objeto de discussão junto ao Poder Judiciário, tendo força de lei entre as partes (art. 468 do CPC). A partir do trânsito em julgado material a sentença que julgar total ou parcialmente a lide, tem força de lei nos limites da lide e das questões decididas (art. 468, CPC). Assim, se as sentenças são meramente terminativas, elas somente fazem coisa julgada formal, mas se são de mérito, fazem coisa julgada material.

Fixa o artigo 468 do CPC que "a sentença, que julgar total ou parcialmente a lide, tem força de lei nos limites da lide e das questões decididas". Fixa assim o legislador os limites objetivos da coisa julgada, ou seja, da extensão da autoridade da coisa julgada, ou sobre o que efetivamente a sentença incide, o que de fato se tornou imutável. Assim, é de suma importância que fiquem claros os limites da coisa julgada material, uma vez que não poderá mais ser objeto de discussão em nenhum outro tribunal. 


\subsection{Coisa JUlgada OBJetiva E SUBJetiva} subjetiva.

A coisa julgada deve também ser considerada em sua dimensão objetiva e

A coisa julgada objetiva se refere à parte dispositiva da sentença que responde ao pedido formulado pelo autor na inicial, e a coisa julgada subjetiva se refere às pessoas atingidas pelos efeitos da coisa julgada, isto é, as partes da relação jurídica, "refere-se à qualidade da sentença, ou seja, à adjetivação do pronunciamento judicial, que ostenta uma condição privilegiada pelo fato de não ter sofrido ataque ou desta investida ter sido rejeitada, mantendo-se a decisão nos termos antes lançados". (MONTENEGRO FILHO, 2007, p. 559).

A coisa julgada impede, portanto, que as questões decididas sejam rediscutidas por outro juiz ou tribunal, pois tal geraria instabilidade e insegurança nas relações processuais, e a segurança jurídica é um dos objetivos principais do direito.

No que tange à dimensão subjetiva da coisa julgada, dispõe o Código de Processo Civil no seu artigo 472: “A sentença faz coisa julgada às partes entre as quais é dada, não beneficiando, nem prejudicando terceiros. Nas causas relativas ao estado de pessoa, se houverem sido citados no processo, em litisconsórcio necessário, todos os interessados, a sentença produz coisa julgada em relação a terceiros". Trata-se, no caso, da coisa julgada inter partes.

Como bem observa Theodoro Júnior (2007, p. 616),

Não quer dizer isto que os estranhos possam ignorar a coisa julgada. Como todo ato jurídico relativamente às partes entre as quais intervém, a sentença existe e vale com respeito a todos. Não é certo, portanto, dizer que a sentença só prevalece ou somente vale entre as partes. O que ocorre é que, apenas a imutabilidade e a indiscutibilidade da sentença não podem prejudicar, nem beneficiar, estranhos ao processo em que foi proferida a decisão transitada em julgado.

tugal:

O mesmo se depreende do artigo $26^{\circ}$ do Código de Processo Civil de Por-

\section{ARTIGO 26 ${ }^{\circ}$}

\section{Conceito de Legitimidade}

1. O autor é parte legítima quando tem interesse directo em demandar; o réu é parte legítima quando tem interesse directo em contradizer.

2. O interesse em demandar exprime-se pela utilidade derivada da procedência da ação; o interesse em contradizer, pelo prejuízo que dessa procedência advenha.

3. Na falta de indicação da lei em contrário, são considerados titulares do 
interesse relevante para o efeito da legitimidade os sujeitos da relação controvertida tal como é configurada pelo autor.

A coisa julgada na sua perspectiva subjetiva, conforme constante dos Códigos de Processo Civil Brasileiro e Português, se orienta na perspectiva do direito individual, de origem liberal, definindo que sentença transitada em julgado somente faz coisa julgada entre as partes.

\subsection{CoISA JULGADA NOS PROCESSOS COLETIVOS}

Há que se observar que o instituto da coisa julgada nos processos coletivos introduz uma nova concepção na processualística, pois na sistemática tradicional do processo civil a coisa julgada produz efeitos tão somente entre as partes envolvidas no litígio, entretanto, o que se busca nas ações coletivas é justamente a ampliação dos efeitos da coisa julgada para pessoas que nem sequer foram partes no processo.

Assim, "aquilo que é exceção no sistema do Código de Processo Civil (a coisa julgada atingir quem não tenha atuado no processo) é regra em se tratando de ações coletivas. Mais do que isso, é da própria essência das ações coletivas". (ALVIM, 2007, p. 175).

Theodoro Júnior (2007, p. 617) também considera a extensão da coisa julgada nos processos coletivos:

A coisa julgada formada no processo coletivo não respeita os limites subjetivos traçados pelo art. 472 do CPC, tanto entre os legitimados para demandar a tutela dos interesses transindividuais como em face das pessoas individualmente lesadas. Há, nesse tipo de processo, possibilidade de eficácia erga omnes (isto é, perante quem não foi parte no processo), embora nem sempre de forma plena.

No campo restrito do interesse transindividual, o sistema observado pela legislação é, em regra, o da coisa julgada erga omnes, atingindo não só as partes ativa e passiva do processo como outras entidades que teriam igual legitimidade para a demanda.

Nos processos coletivos torna-se necessária a flexibilização no tocante à dimensão subjetiva da coisa julgada, torna-se imperativo romper com a visão liberal de um direito privatista para um direito social, que contemple a sociedade, os grupos nela inseridos, objetivando a realização da justiça em face de todos que porventura tenham sido lesados em seus direitos.

Grinover (2003, p. 53) observa que a lei portuguesa adotou dois critérios quanto à coisa julgada: 
a) como regra geral, o regime da coisa julgada erga omnes, para os casos de procedência ou improcedência, salvo quando esta se der por insuficiência de provas (art. 19, 1);

b) para os que tenham exercido o direito de auto-exclusão, sua indiferença à coisa julgada, seja a sentença positiva ou negativa (art. 19, 1).

Desse modo, a Lei $n^{\circ} 83 / 95$ combinou dois critérios, sendo o primeiro familiar ao sistema brasileiro, e o segundo próprio do ordenamento norte-americano.

Com efeito, é típico das leis brasileiras sobre ação popular e ação civil pública a adoção de uma coisa julgada erga omnes, com o temperamento da inexistência de coisa julgada nos casos de improcedência por insuficiência de provas (com o que se evita o risco de colusão entre as partes), sempre que se trate de direitos de objeto indivisível (interesses difusos e coletivos):

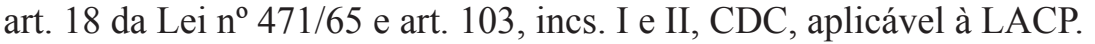

Mas o critério do opt out e do opt in, como forma de submissão, ou não, do terceiro ao julgado, é próprio das class actions. A rule 23, c 2 e c 3 das Federal Rules de 1966 expressamente prevê a possibilidade de optar-se pela exclusão da coisa julgada, sendo abrangidos por ela aqueles que, informados da demanda "da maneira melhor segundo as circunstâncias" (inclusive mediante intimação pessoal, quando as pessoas forem passíveis de identificação), não tiverem procedido ao pedido de exclusão. É o critério denominado op out, recentemente reafirmado pela Suprema Corte norte-americana, que dispensou os demais, não optantes pela exclusão, de expresso consentimento para integrar a demanda (o que corresponderia ao critério do opt in). Em outras palavras, adotado o critério do opt out, os que deixam de optar pela exclusão serão automaticamente abrangidos pela coisa julgada, sem necessidade de anuência expressa, mas desde que tenha havido notícia do ajuizamento da ação.

Este critério, adotado pelo legislador português encontra-se insculpido no artigo $15^{\circ}, 1$ e 2 da Lei 83/95:

1. Recebida a petição de acção popular, serão citados os titulares dos interesses em causa na acção de que se trate, e não intervenientes nela, para o efeito de, no prazo fixado pelo juiz, passarem a intervir no processo a título principal, querendo, aceitando-o na fase em que se encontrar, e para declararem nos autos se aceitam ou não ser representados pelo autor ou se, pelo contrário, se excluem dessa representação, nomeadamente para o efeito de lhes não serem aplicáveis as decisões proferidas, sob pena de a sua passividade valer como aceitação, sem prejuízo do disposto no $n^{\circ} 4$.

2. A citação será feita por anúncio ou anúncios tornados públicos atra- 
vés de qualquer meio de comunicação social ou editalmente, consoante estejam em causa interesses gerais ou geograficamente localizados, sem obrigatoriedade de identificação pessoal dos destinatários, que poderão ser referenciados enquanto titulares dos mencionados interesses, e por referência à acção de que se trate, à identificação de pelo menos o primeiro autor, quando seja um entre vários, do réu ou réus e por menção bastante do pedido e da causa de pedir.

Nicolau Santos Silva (2002, p. 115) considera esta sistemática do direito português:

Assim, as sentenças têm, em princípio, efeitos que se estendem a todas as pessoas titulares do interesse que não se auto-excluíram da lide, ou seja, a sentença não produz apenas efeitos relativamente às partes, pois, como o interesse supra-individual diz respeito a um número determinado ou indeterminado de indivíduos, se a decisão final da causa não fugisse aos limites clássicos do caso julgado, de nenhum interesse se revestiria, porquanto, a conflitualidade que a acção pressupõe continuaria a existir relativamente aos restantes titulares do interesse supra-individual podendo estes intentar outras acções, com o mesmo pedido e causa de pedir, com manifesto prejuízo para a economia processual e, mais grave, a pluralidade de acções poderia originar casos julgados contraditórios, com prejuízo para a certeza e segurança jurídicas.

O legislador brasileiro, diferentemente do legislador português, optou por adotar o sistema da coisa julgada secundum eventum litis. A este respeito observa Alvim:

De outro modo, deve-se consignar que a adoção da regra da coisa julgada secundum eventum litis pelo sistema do Código do Consumidor, e que norteia todas as ações de natureza coletiva, teve como base o sistema americano das class actions, sofrendo, todavia, como se verá adiante, mutações para adequar-se à realidade brasileira.

No sistema americano exige-se que a associação ou outro ente legitimado comprove que efetivamente representa os associados (adequacy of representation) e que todos os associados sejam informados da existência da ação (fair notice), para que possam optar entre aderir à ação, não se manifestar ou sair da ação. Verifica-se, assim, que o sistema americano não adotou o sistema da coisa julgada secundum eventum litis, uma vez que o indivíduo será ou não beneficiado conforme a sua opção de se sujeitar ou não à ação coletiva. 
O sistema americano possui, sem dúvida, grandes méritos ao possibilitar que o indivíduo exerça discricionariamente a opção de participação ou não da ação. Todavia, essa sistemática não poderia ser adotada na íntegra pelo direito brasileiro, como de fato não o foi (adotou o sistema da coisa julgada secundum eventum litis), tendo em vista as diferenças sociais e culturais da população, que poderia, com facilidade, comprometer a liberdade com que o indivíduo opta por aderir ou não à ação coletiva. (ALVIM, 2007, pp. 176-177).

O Código de Defesa do Consumidor adotou a sistemática da coisa julgada sedundum eventum lites. A esse respeito, Alvim (2007, p. 178) sobre a coisa julgada em processos coletivos envolvendo direitos difusos considera:

$\mathrm{O}$ art. 103, I (que é correspondente à hipótese do art. 81, parágrafo único, I), dispõe que a coisa julgada, em caso de ação que tenha por objeto interesses difusos, será erga omnes, "exceto se o pedido for julgado improcedente por insuficiência de provas, hipótese em que qualquer legitimado poderá intentar outra ação, com idêntico fundamento valendo-se de nova prova, na hipótese do inc. I do parágrafo único do art. 81”. Esta caracteriza-se, nos termos do art. 103, I, por atingir a todos indistintamente. O alcance subjetivo da coisa julgada, nesse caso, dependerá, como já dito, do resultado da demanda. Vejamos. A coisa julgada somente atingirá a todos os legitimados a atuar coletivamente, e a qualquer indivíduo isoladamente considerado, tal como ocorreria com o exercício do direito individual de ação, caso seja a ação coletiva julgada procedente. A hipótese da possibilidade de repetição da mesma ação civil coletiva, i.e., de um novo atuar no processo coletivo, dependerá de a ação ter sido julgada improcedente por deficiência de prova e de que nova prova seja produzida e havida como tal pelo juiz, numa segunda demanda coletiva. Se for julgada improcedente, sem ter sido por deficiência da prova, não poderá vir a ser repetida ação coletiva, mas as ações individuais podem ser propostas (é o que dispõe o $\S 1^{\circ}$ do art. 103, em relação às hipóteses do art. 81, parágrafo único, I e II, correlatamente aos incs. I e II do art. 103, rezando esse $\S 1^{\circ}$ : " $\$ 1^{\circ}$ Os efeitos da coisa julgada previstos nos incs. I e II não prejudicarão interesses e direitos individuais dos integrantes da coletividade, do grupo, categoria ou classe".

Acerca das implicações da coisa julgada secundum eventum lites no caso dos direitos coletivos, também considera Alvim (2007, p. 181):

De outro lado, se a hipótese disser respeito a direitos coletivos (art. 103, 
II, do CDC), a coisa julgada operará efeitos ultra partes, limitadamente ao grupo, categoria ou classe, isto é, atinge quem não tenha sido parte, salvo o caso de improcedência por falta de provas.

A coisa julgada aqui é ultra partes e não erga omnes, como no primeiro caso (art. 103, I, do CDC), porque, apesar de atingir quem não tenha sido parte, limita-se ao grupo, categoria ou classe.

No caso de direitos difusos, todos os da coletividade são atingidos com a coisa julgada, enquanto no caso dos direitos coletivos, são atingidos os membros de um grupo, categoria ou classe.

Alvim (2003, pp. 185-186) aponta agora as implicações da coisa julgada secundum eventum lites no caso dos direitos individuais homogêneos.

Diferentemente do que ocorre com a coisa julgada referente aos interesses difusos e coletivos, no caso dos interesses individuais homogêneos a não ocorrência da coisa julgada e a possibilidade de repropositura da ação não se vinculam à extinção da ação por insuficiência de provas, sendo que somente haverá coisa julgada erga omnes na hipótese de procedência do pedido. Em caso de improcedência da ação (qualquer que seja a causa), aqueles que não estiverem habilitados como litisconsortes poderão propor ações de indenização individuais.

O legislador português optou pelo sistema do opt out e opt in.

Os titulares dos "interesses em causa" são citados para, querendo, intervir no processo a título principal e para declarar nos autos se aceitam ser representados pelo autor (opt in) ou se se excluem dessa representação (opt out), entendendo-se a passividade como aceitação (art. 15), ressalvado o direito de ainda a recusarem expressamente até o término da fase probatória (art. 15.4). (GRINOVER, 2000, p. 54).

O artigo 152 dispõe que a citação se faça pelos meios de comunicação de massa ou através de edital, sem obrigatoriedade de identificação pessoal do destinatário, e o inciso $\mathrm{n}^{0} 3$ dispõe que a citação se faça "por referência ao respectivo universo, determinado a partir de circunstância ou qualidade que lhe seja comum, da área geográfica em que residam ou do grupo ou comunidade a que pertençam”.

Sousa (2003, p. 211) considera a autoexclusão no direito português:

A admissibilidade da auto-exclusão dos titulares do interesse difuso não pode valer em relação a todo e qualquer objecto da acção popular, porque só faz sentido utilizar esta faculdade quando o titular não for necessaria- 
mente abrangido pelo caso julgado da decisão proferida na acção popular. Para este efeito, é fundamental considerar a distinção entre os interesses difusos stricto sensu e os interesses colectivos, pois que, sempre que o objecto da acção popular respeite àqueles interesses difusos, a faculdade de auto-exclusão não pode ser admitida. Se, por exemplo, o tribunal considerar que a poluição deve terminar imediatamente, que uma discriminação no emprego em função do sexo deve cessar ou ainda que o produto, por ser considerado defeituoso, deve ser retirado do mercado, não tem sentido admitir que a obrigação do poluidor, do empregador ou do produtor não deve valer perante qualquer interessado.

Pertinente a observação de Sousa, em estabelecer limites para a utilização do opt out, pois necessariamente nesse caso a coisa julgada teria efeitos erga omnes, independentemente da vontade do indivíduo. Com as ressalvas postas por Sousa, ainda assim, parece-nos que tem razão Grinover (2000, p. 54) ao fazer a seguinte avaliação crítico-comparativa do sistema do opt out e opt in do direito português com o direito brasileiro:

Pode ser que o sistema dê certo em Portugal, país pequeno e habitado por pessoas mais esclarecidas e conscientizadas. Mas já suscitou enormes problemas nos Estados Unidos da América, onde a Suprema Corte chegou a afirmar que a orientação pela qual o membro da class, que não tenha optado expressamente pela exclusão, seria abrangido pela coisa julgada, depende de sua intimação pessoal, sob pena de não se poder entender que fora adequadamente informado. E certamente não se adaptaria à realidade existente no Brasil, país de dimensões continentais, deparando com enormes problemas de informação completa e correta, de falta de conscientização de parcela ingente da população, de desconhecimento sobre os canais de acesso à Justiça, de grande distanciamento entre o povo e os tribunais, tudo a desaconselhar a extensão da coisa julgada, quando desfavorável a sentença, a quem não integrou a relação processual e só foi artificialmente "representado" pelo portador em juízo dos interesses coletivos.

Por isso, a eficácia erga omnes do julgado, favorável ou desfavorável, só foi adotada, no Brasil, para os interesses indivisíveis (difusos e coletivos), em que não há mesmo como cindir o comando da sentença que, por sua própria natureza, deverá abranger toda a classe, categoria ou grupo, com o temperamento da inexistência de coisa julgada em caso de improcedência por insuficiência de provas (art. 18 da Lei da Ação Popular e art. 103, incs. I e II, CDC, aplicável à LACP).

Mas, para os interesses individuais homogêneos, divisíveis por natureza e com titulares individualizados (ou individualizáveis), a lei adotou o es- 
quema da coisa julgada erga omnes, mas secundum eventum litis: ou seja, em caso de sentença favorável, todos os componentes do grupo, classe ou categoria serão beneficiados; mas, em caso de sentença desfavorável, a coisa julgada operará somente para impedir novas demandas coletivas, ficando aberta aos interessados, que não tiverem intervindo no processo como litisconsorte, a via das ações individuais (art. 103, inc. III e $\S 2^{\circ}$, $\mathrm{CDC}$, aplicável à LACP).

Penso que, de fato, a sistemática adotada pelo legislador brasileiro é mais adequada à realidade brasileira, uma vez que muitos não têm acesso à informação, e que a veiculação por um meio de comunicação que a maioria das pessoas tem acesso, no caso a televisão, custa muito caro. O fato é que tais sistemas devem levar em conta a realidade sócio-cultural do povo. E me parece que o legislador brasileiro assim o fez como, certamente, também o fez o legislador português.

\section{Avaliação da aplicabilidade da aÇão popular no direito brasileiro e NO DIREITO PORTUGUÊS}

A ação popular (Lei 83/95) é em Portugal, o instrumento principal para a tutela dos direitos coletivos, enquanto que no Brasil vários instrumentos visam à proteção dos referidos direitos como a Lei da Ação Civil Pública (Lei 7.437/85 e CF/88, art. 129, III), Código de Defesa do Consumidor (Lei 8.078/90), mandado de segurança coletivo (CF/88, art. 5 LXX), ação popular $\left(\mathrm{CF} / 88\right.$, art. $5^{\circ}$, LXXIII), dentre outros.

O artigo 83 do CDC dispõe que "para a defesa dos direitos e interesses protegidos por este Código são admissíveis todas as espécies de ações capazes de propiciar sua adequada e efetiva tutela".

Neste aspecto o legislador brasileiro agiu com grande flexibilidade, condição imprescindível nas ações que versam sobre direitos coletivos, no que o legislador português se mostrou um tanto reticente, pois poderia ter conferido a mesma amplitude através do Direito do Consumidor (Lei 24/96).

Por sua vez, a ação popular brasileira volta-se para a anulação de ato lesivo ao "patrimônio público ou entidade que o Estado participe, à moralidade administrativa, ao meio ambiente e ao patrimônio histórico e cultural", sendo que tem legitimidade para propor a ação popular qualquer cidadão.

Além da ação popular, há no Brasil a Ação Civil Pública, que é o instrumento por excelência para a tutela dos interesses coletivos.

Otero (1999, p. 885) aponta várias implicações da Lei 83/95:

a) Resulta evidente, desde logo, que a acção popular agora prevista, expressando exigências de índole constitucional, se mostra dotada de um 
campo de operatividade muito superior àquele que resultava dos artigos $369^{\circ}$ e $822^{\circ}$ do Código Administrativo de 1940:

(i) A Lei 83/95, de 31 de Agosto, transformou a acção popular de simples mecanismo de controlo da Administração em instrumento de tutela jurisdicional de certos interesses comuns da colectividade cuja lesão ou ameaça de lesão pode também ser provocada pela actividade desenvolvida por entidades privadas;

(ii) A tradicional operatividade vertical da acção popular foi objecto, deste modo, de um verdadeiro processo de horizontalização: a acção popular surge hoje também como instrumento processual de particulares contra acções ou omissões de outros particulares;

(iii) Ao lado da acção popular individual e da acção popular colectiva, a lei criou - isto sem que a Constituição exigisse, note-se - uma dupla acção popular pública:

- Uma acção popular pública originária, enquanto decorrência do reconhecimento às autarquias locais de legitimidade processual activa;

- Uma acção popular pública derivada ou superveniente, expressão da possibilidade de intervenção processual substitutiva do Ministério Público, designadamente em casos de desistência da lide ou de transacção;

a) A segunda ilação é que estamos aqui diante de um meio garantístico dotado de significativas inovações processuais que se podem resumir em três idéias centrais:

(i) Existência de claros estímulos à utilização deste meio processual para a defesa dos interesses materiais em causa;

(ii) Preocupação de assegurar a máxima amplitude da eficácia subjectiva do caso julgado;

(iii) Reforço da intervenção processual do juiz.

a) A terceira ilação diz respeito às especiais inovações que a acção popular comporta ao nível do contencioso administrativo: o regime legal da acção popular representa uma verdadeira revolução no contexto do entendimento e da configuração do recurso contencioso de anulação.

Otero faz estas análises em 1999, logo, quatro anos após a publicação da Lei 83/95. Esta apresentava suas primeiras manifestações judiciais, e foi saudada pelo ilustre jurista lusitano como uma verdadeira inovação no direito português, além de causar uma "verdadeira revolução" no contencioso administrativo.

Otero teve a exata percepção das implicações da Ação Popular no direito português, reconhecendo as suas múltiplas aplicações face aos interesses e direitos, objetivando "promover a prevenção, a cessação ou a perseguição judicial das infracções contra a saúde pública, os direitos dos consumidores, a qualidade de vida e a preservação do ambiente e do patrimônio cultural" (art. 52, 3, a, da CRP c/c art. $1^{\circ}$ 
da lei 83/95).

Se compararmos a Ação Popular Portuguesa com a Ação Civil Pública no Brasil, veremos que elas têm muitas semelhanças, entretanto a legitimidade para a propositura da Ação Civil Pública é bem mais ampla que na Ação Popular Portuguesa, uma vez que figuram como legitimados o Ministério Público e a Defensoria Pública, além de associações específicas, não obstante não possa propô-la o cidadão, diferentemente do que ocorre em Portugal, uma vez que o cidadão brasileiro somente tem legitimidade para propor a Ação Popular para anular atos lesivos praticados pela Administração Pública nos termos acima referidos.

Observa-se, também, que o legislador brasileiro fez questão de deixar claro que os danos morais e patrimoniais elencados no artigo $1^{\circ}$ da Lei $7.347 / 85$ são meramente exemplificativos, uma vez que no inciso IV fez constar: "a qualquer outro interesse difuso ou coletivo". Não se percebe a mesma clareza na Lei 83/95, uma vez que não traz menção expressa sobre a não-taxatividade do artigo $1^{\circ}$. Entretanto, considerando a flexibilização que os direitos coletivos e a ações correspondentes exigem, é razoável pensar que o mesmo é tão somente exemplificativo.

Quanto à legitimidade para o ajuizamento da ação popular, há semelhanças com o sistema processual coletivo, em se considerando a Ação Civil Pública e o Código de Defesa do Consumidor, além da específica ação popular brasileira.

Não obstante a Lei 83/95 conferir ampla legitimidade aos cidadãos portugueses, pessoas coletivas, autarquias locais e, excepcionalmente, ao Ministério Público, para a propositura da ação popular, procurou estabelecer instrumentos de controle. Assim, caso perceba o Ministério Público que o autor está praticando atos lesivos em relação aos interesses defendidos em causa, pode substituí-lo, assumindo o pólo ativo da relação processual, nos termos do artigo 16, n. 3 da Lei 83/95. O juiz também, desde que fundado em motivações de cada caso concreto, pode restringir os efeitos da coisa julgada, não obstante a procedência da demanda, inclusive limitando seus efeitos às partes que integraram os pólos processuais da demanda.

No que se refere à coisa julgada, observa-se que no Brasil a sentença proferida em ação civil pública faz coisa julgada em duas hipóteses: a) em caso de improcedência do pedido, fazendo coisa julgada ultra partes (artigo 103, II do CDC) para atingir os titulares do direito supra-individual (difuso ou coletivo), o que impede os legitimados constantes do artigo 82 do CDC a propor novamente a mesma demanda (ação coletiva), mas não impede que ações individuais com vistas a tutelar direitos individuais continuem podendo ser propostas, inclusive as referentes a direitos individuais homogêneos; b) em caso de procedência, a sentença de natureza coletiva faz coisa julgada erga omnes (art. 103, I e III do CDC) ou ultra partes (art. 103, II do $\mathrm{CDC}$ ) e obstará a que se proceda à proposição de nova ação civil coletiva com o mesmo objeto.

Em caso de improcedência do pedido por insuficiência de provas, a sentença não faz coisa julgada. 
No caso do direito português, houve uma mescla de elementos do direito norte-americano com elementos do direito brasileiro. Desta forma, num primeiro momento, tanto para os casos de procedência como para os de improcedência, a sentença decorrente de ação popular produz coisa julgada erga omnes, salvo quando a improcedência for devida à insuficiência de provas (art. 19, n. 1, da LAP), critério este que é adotado pelo direito coletivo brasileiro. Por outro lado, é facultado aos cidadãos portugueses o exercício do direito de auto-exclusão em algumas ações coletivas (arts. $19^{\circ}$, n. 1, e 15 , n. 1, ambos da LAP). De acordo com este critério, os que optarem pela autoexclusão não serão atingidos pela coisa julgada coletiva. Tal critério é característico das class actions do direito norte-americano.

Por fim cabe fazer considerações referentes ao poder do juiz na ação popular portuguesa e na ação civil pública brasileira.

Ao estabelecer esta comparação, constata-se que tanto na ação popular quanto na ação civil pública o juiz goza de amplos poderes.

Como observa Grinover (2000, p. 57), “todo o direito processual moderno caminha hoje ruma à ampliação dos poderes do juiz, não mais visto como espectador inerte, mas como protagonista principal da relação processual". Nas demandas coletivas exige-se ainda mais participação do juiz, tendo em vista os contornos políticos da atuação judicial, uma vez que seu corolário é de natureza política.

A Lei 83/95, em seu artigo 17 atribui ao juiz iniciativa própria em matéria de colheita de prova.

Grinover (2000, p. 57) cita alguns exemplos de iniciativa judicial do juiz na legislação brasileira.

Assim, apenas para exemplificar, o juiz pode conceder mandado liminar, inaudita altera parte (art. 12, LACP); nas obrigações de fazer ou não fazer, pode julgar extra petita, aplicando o regime das astreintes ainda que o autor não o tenha requerido; e mais, no campo da tutela específica, o juiz pode determinar providência sub-rogatórias, mediante ordens impostas ao devedor ou a terceiros para chegar a um resultado prático equivalente ao adimplemento (art. 11, LACP, ampliado pelo CDC que, em seu art. 84, exemplifica, entre as medidas sub-rogatórias, mencionando a busca e apreensão, o desfazimento de obra, a remoção de pessoas ou coisas, o impedimento da atividade nociva, além de requisição de força policial).

O juiz, em Portugal, pode ainda indeferir liminarmente a petição inicial que demonstrar ser manifestamente improvável a procedência do pedido, nos termos do art. $13^{\circ}$, o que não é contemplado pela legislação brasileira. O juiz pode restringir a eficácia geral das sentenças provenientes de ação popular, desde que se fundamentando em motivações próprias do caso concreto (art. 19º 1 , da Lei 83/95), o que não é possível ao juiz brasileiro ao julgar na ação civil pública. 
Ainda pode o juiz, nos termos do artigo $18^{\circ}$ da Lei 83/95, conferir efeito suspensivo a recurso que não tenha efeito suspensivo para evitar dano irreparável ou de difícil reparação, o que também é contemplado pelo artigo 14 da Lei n. 7.437/85 (LACP).

Pode ainda o juiz brasileiro, nos termos da LACP, suspender a execução de liminar, em decisão fundamentada, para evitar grave lesão à ordem, à saúde, à segurança e à economia pública (art. 12, § $1^{\circ}$ da LACP). "Poderá o juiz conceder mandado liminar, com ou sem justificação prévia, em decisão sujeita a agravo" (art. 12, caput, da LACP). Enfim, a LACP confere grande iniciativa ao juiz na condição das ações civis públicas objetivando a preservação e garantia de direitos.

\section{Conclusão}

Em que pesem as diferenças entre as tutelas coletivas no Brasil e em Portugal, há também muitas semelhanças entre elas, e o que se observa é que a tutela coletiva tem despertado grande interesse no âmbito jurídico dos dois países.

É certo que a tutela coletiva tem uma maior abrangência no direito brasileiro, e tem sido objeto de estudo e discussões bem mais abrangentes entre os operadores do direito no Brasil, haja vista o Anteprojeto do Código de Processo Civil e seu correspondente projeto de lei (5.139/2009), que foi rejeitado pela Comissão de Constituição e Justiça do Congresso Nacional em março de 2.010, mas que contribuiu para a discussão sobre a necessidade de aperfeiçoamento dos institutos processuais coletivos.

Há que se considerar que o Brasil é um país de dimensões continentais, com um elevado contingente populacional e que enfrenta grandes problemas de ordem econômica, social e ambiental. As peculiaridades da realidade social brasileira certamente pesam, pendendo para o advento de institutos jurídicos voltados para a tutela coletiva, tanto no âmbito do direito material como no âmbito do direito processual.

Ainda que muitos operadores do direito no Brasil tenham uma formação liberal, tendo sido treinados a operar orientados por este paradigma, o certo é que muitas transformações têm ocorrido no sistema jurídico em razão das ações coletivas, operando uma mudança de paradigma nos operadores do direito no Brasil.

O movimento em prol de uma jurisdição coletiva cresce continuamente no Brasil, sendo que muitos juristas estão empenhados em lutar por sua implantação.

Em Portugal, todavia, as discussões relativas à tutela coletiva são mais parcimoniosas. Atualmente, as preocupações parecem se voltar muito mais para o "direito comunitário", tendo em vista as decisões normativas tomadas pela União Europeia e que repercutem diretamente na sociedade portuguesa, exigindo a adequação de seus institutos jurídicos.

O legislador português legisla levando em conta sua realidade social. E as 
diferenças sociais e culturais entre Brasil e Portugal não são poucas. O direito coletivo em Portugal tem merecido atenção do legislador e dos operadores do direito. $\mathrm{O}$ Brasil, por sua vez, mesmo tendo leis avançadas no âmbito da tutela coletiva, experimenta uma grande dificuldade quanto à sua aplicação prática. É muito difícil, no sistema jurídico brasileiro, penalizar os administradores públicos ou obrigar aqueles que, com suas condutas lesam o patrimônio público, o meio ambiente etc., a repararem seus erros, pois o Poder Judiciário é moroso, e quando uma sentença é proferida geralmente o administrador público já chegou a concluir o seu mandato.

Em Portugal, por sua vez, ocorre, conforme indicativos da União Europeia, uma prestação jurisdicional superior à realizada no Brasil.

Ao que tudo indica, Brasil e Portugal deverão avançar ainda mais na construção de uma tutela coletiva consentânea com as demandas sociais, buscando a realização da justiça ao maior número de pessoas.

\section{REFERÊNCIAS}

ALMEIDA, Gregório Assagra de. Direito Processual Coletivo Brasileiro. Um novo ramo do direito processual. São Paulo: Saraiva, 2003.

ALVIM, Eduardo Arruda. Coisa Julgada e Litispendência no Anteprojeto de Código Brasileiro de Processos Coletivos. In: Código Processual Coletivo e o anteprojeto de Código Brasileiro de Processos Coletivos. São Paulo: RT, 2007.

BOBBIO, Norberto. A Era dos Direitos. 10. ed., Rio de Janeiro: Campus, 1992.

FERRARESI, Eurico. A Pessoa Física como Legitimada Ativa à Ação Coletiva. In: Direito Processual Coletivo e o anteprojeto de Código Brasileiro de Processos Coletivos. São Paulo: RT, 2007.

GRINOVER, Ada Pellegrini. A Marcha do Processo. Rio de Janeiro: Forense Universitária, 2000.

GRINOVER, Ada Pellegrini. Direito Processual Coletivo. In: GRINOVER, Ada Pellegrini, MENDES, Aluisio Gonçalves de Castro e WATANABE, Kazuo. Direito Processual Coletivo e o anteprojeto de Código Brasileiro de Processos Coletivos. São Paulo: RT, 2007.

MAZZILI, Hugro Nigro. A Defesa dos Interesses Difusos em Juizo. São Paulo: Saraiva, 9. ed., 1997.

MONTENEGRO FILHO, Misael. Curso de Direito Processual Civil. 4. ed., São Paulo: Atlas, 2007.

OTERO, Paulo. Instituições Políticas e Constitucionais, Vol. I. Coimbra: Almedia, 2009. 
OTERO, Paulo. A Acção Popular: Configuração e valor no actual Direito português. In: Revista da Ordem dos Advogados, Ano 59, Lisboa: Edição do Centro Livreiro da Ordem dos Advogados, 1999.

QUEIROZ, Cristina. Direitos Fundamentais Sociais. Funções, âmbito, conteúdo, questões interpretativas e problemas de justiciabilidade. Coimbra: Coimbra Editora, 2006.

SANTOS, Cecília - BDJUR (org.) Constituição da República Portuguesa. Coimbra: Almedina, 2009.

SILVA, F. Nicolau dos Santos. Os interesses supra-individuais e a legitimidade processual civil activa. Lisboa: Quid Júris?, 2002.

SOUSA, Miguel Teixeira. A Legitimidade Popular na Tutela dos Interesses Difusos. Lisboa: Almedina, 2003.

THEODORO JÚNIOR, Humberto. Curso de Direito Processual Civil, Vol. I, 47. ed., Rio de Janeiro: Forense, 2007. 